\title{
Gentamicin-vancomycin-colistin local antibiotherapy in a cement spacer in a 54-year-old haemophilic patient with relapsing plurimicrobial severe prosthetic joint infection
}

\author{
Tristan Ferry, ${ }^{1,2,3,4}$ Romain Desmarchelier, ${ }^{5}$ Sophie Magréault, ${ }_{1}^{6,7}$ Florent Valour, ${ }^{1,2,3,4}$ on \\ behalf of the Lyon BJI Study group
}

'Service de Maladies Infectieuses et Tropicales, Hôpital de la Croix-Rousse, Hospices Civils de Lyon, Lyon, France

${ }^{2}$ Université Claude Bernard Lyon 1, Lyon, France

${ }^{3}$ Centre International de Recherche en Infectiologie, CIRI, Lyon, France

${ }^{4}$ Centre Interrégional de Référence des Infections Ostéoarticulaires complexes (CRIOAC Lyon), Hospices Civils de Lyon, Lyon, France

${ }^{5}$ Service de Chirurgie orthopédique et de

Traumatologie, Centre Hospitalier Lyon Sud, Hospices Civilsde Lyon, Lyon, France

${ }^{6}$ Laboratoire Pharmacologie des anti-infectieux, Inserm U-1070, Poitiers, France

${ }^{7}$ Université de Poitiers, UFR Médecine-Pharmacie, Poitiers, France

Correspondence to Pr Tristan Ferry, tristan.ferry@univ-lyon1.fr

Accepted 1 October 2017

CrossMark

\begin{tabular}{|l|}
\hline To cite: Ferry T, \\
Desmarchelier R, Magréault S, \\
et al. BMJ Case Rep \\
Published Online First: \\
[please include Day Month \\
Year]. doi:10.1136/bcr-2017- \\
221743 \\
\hline
\end{tabular}

To cite: Ferry $T$,

Desmarchelier R, Magréault $S$, et al. BMJ Case Rep

Published Online First:

please include Day Month
Yearl. doi:10.1136/bcr-2017

221743

\section{DESCRIPTION}

A 54-year-old patient with haemophilia and hepatitis $C$ virus infection experienced acute left prosthetic joint infection due to Klebsiella pneumoniae and Staphylococcus aureus following unipolar exchange in September 2015. As the outcome was not favourable with bloody discharge despite haemophilic factor substitution, a new local debridement was performed in May 2016 and multidrug-resistant Enterobacter asburiae (only susceptible to imipenem, colistin, amikacin and fosfomycin) and Corynebacterium striatum (only susceptible to vancomycin, rifampin and linezolid) grew in cultures. As explantation was considered too risky due to the potential bleeding, systemic intravenous treatment was proposed with imipenem ( $3 \mathrm{~g} /$ day $)$, vancomycin $(2.5 \mathrm{~g} /$ day $)$ and fosfomycin (12 g/day). After 3 months of therapy, the bloody discharge persisted. One month after discontinuation of antibiotics, the patient presented a large 'bourgeon charnu' with impressive bloody discharge (figure 1A). X-ray revealed trochanter osteolysis, without prosthesis loosening (figure 1B). Prosthesis explantation was performed, and a commercial articulated spacer was inserted. We used the COPAL $\mathrm{G}+\mathrm{V}$, which delivers locally a high amount of gentamicin and vancomycin. To have an activity against the Gram-negative pathogen, we decided to add 6 MUI of Colimycine to each dose of cement even if few data were available on this practice. ${ }^{1}$ A total of five doses were required to do the articulated spacer (figure 1C), leading to a total local dose of 30 MUI of colimycin. Additionally, the patient received as empirical therapy meropenem $(6 \mathrm{~g} /$ day $)$ and daptomycin $(700 \mathrm{mg} /$ day $)$. Colistin (the active form of Colimycine) concentrations were measured locally from suction drainage fluid and in plasma (to ensure that there is no systemic diffusion) using liquid chromatography. High concentrations of colistin were measured locally during several days, 32 times (at day 1) and 5 times (at day 4) above the E. asburiae colistin minimum inhibitory concentration $(\mathrm{MIC}=0.125 \mathrm{mg} / \mathrm{L})$. Cultures of per operative samples yielded the same E. asburiae, but not the Corynebacterium. Colistin concentration in plasma was below the limit of quantification set at $0.04 \mathrm{mg} / \mathrm{L}$. Colistin was then administered systemically at day 5 , taking over the local administration. The outcome was initially favourable, but
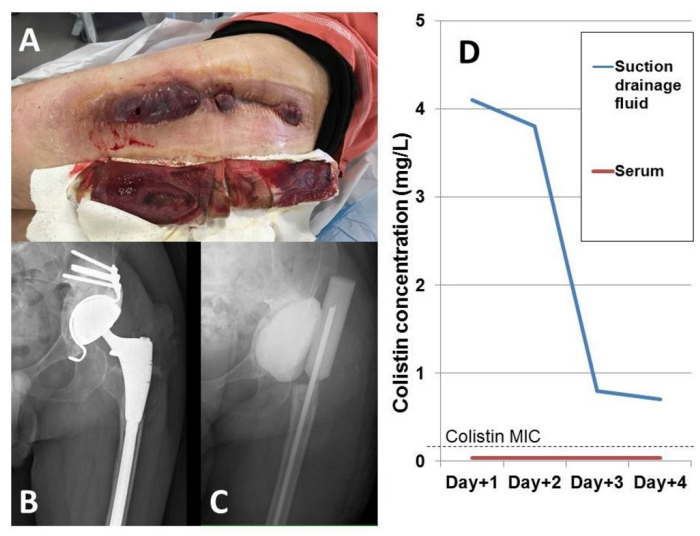

Figure 1 Local (A) and radiological (B) aspects before prosthesis explantation; radiological aspect of the antibiotic-loaded articulated spacer, after prosthesis explantation (C); colistin concentrations in the suction drainage fluid and in plasma (D). MIC, minimum inhibitory concentration.

debridement and spacer explantation were required several weeks later as haematoma with bloody discharge occurred. Superinfection with Enterococcus faecalis and Candida albicans was detected and treated. The E. asburiae was never found again. Nine months later, a small intermittent haemorrhagic discharge was still observed, making prosthesis reimplantation impossible.

Articulated spacers are currently used in patients with knee prosthesis infection, as they are associated with significant improvement of clinical results and knee functionality after reimplantation. ${ }^{2}$ Moreover, in prosthetic joint infections, there is growing evidence concerning the potential efficacy of antibiotic-loaded spacer that provides a high local concentration of antibiotic. ${ }^{3}$ Commercially or locally

\section{Learning points}

- Antibiotic-loaded spacer delivers high concentrations of colistin locally, without systemic diffusion.

- Combination of local antimicrobials could be useful for the treatment of multidrug-resistant prosthetic joint infection. 
made gentamicin or vancomycin spacers are usually used in this indication. Facing polymicrobial prosthetic joint infection with multidrug-resistant pathogens, it could be useful to use a combination of antibiotics in the spacer. Gentamicin and vancomycin are synergistic against staphylococci and might also prevent superinfection with these pathogens. Here, awaiting the culture results, the addition of colimycin in the spacer allowed high local concentrations of colistin, with no potential of systemic toxicity.

Contributors TF designed the management of the patient with the antibioticloaded spacer and wrote the draft of the manuscript. All authors (TF, RD, SM and FV) participated in the patient care, the literature review and the improvement of the manuscript. SM performed the measurements of colistine.

Competing interests None declared.
Patient consent Obtained.

Provenance and peer review Not commissioned; externally peer reviewed.

(C) BMJ Publishing Group Ltd (unless otherwise stated in the text of the article) 2017. All rights reserved. No commercial use is permitted unless otherwise expressly granted.

\section{REFERENCES}

1 Krajewski J, Bode-Böger SM, Tröger U, et al. Successful treatment of extensively drugresistant Pseudomonas aeruginosa osteomyelitis using a colistin- and tobramycinimpregnated PMMA spacer. Int J Antimicrob Agents 2014;44:363-6.

2 Vasso M, Del Regno C, Corona K, et al. Articulated spacer provides long-term knee improvement after two-stage reimplantation. Knee Surg Sports Traumatol Arthrosc 2016;24:3100-5.

3 Bertazzoni Minelli E, Benini A, Samaila E, et al. Antimicrobial activity of gentamicin and vancomycin combination in joint fluids after antibiotic-loaded cement spacer implantation in two-stage revision surgery. J Chemother 2015;27:17-24.

Copyright 2017 BMJ Publishing Group. All rights reserved. For permission to reuse any of this content visit http://group.bmj.com/group/rights-licensing/permissions.

BMJ Case Report Fellows may re-use this article for personal use and teaching without any further permission.

Become a Fellow of BMJ Case Reports today and you can:

- Submit as many cases as you like

- Enjoy fast sympathetic peer review and rapid publication of accepted articles

- Access all the published articles

- Re-use any of the published material for personal use and teaching without further permission

For information on Institutional Fellowships contact consortiasales@bmjgroup.com

Visit casereports.bmj.com for more articles like this and to become a Fellow 